\title{
濃尾平野の超深層地下水の水質とラドン濃度の時期的変動
}

茶谷邦男*，加賀美忠明*，富田伴一*， 大沼章子*，荘加 泰司*，浜村憲克*

\section{Seasonal Variations of Quality and Radon Conterts of Ultra Underground Water in the Nobi Plain}

\author{
Kunio ChayA**, Tadaaki Kagami**, Ban-ichi Tomita*, \\ Shoko Ohnuma**, Taiji ShoKA**, Norikatsu Hamamura**
}

\begin{abstract}
On the underground of the Nobi plain, the sedimentary layers exist over 1,500m thick. In the lowest part of these layers, there is the ultra underground water which temperature is about $50^{\circ} \mathrm{C}$. We determined quality and Radon contents of the waters of 11 wells situated in the left bank of Kiso river. For the seasonal variation study one of these wells was continuously observed once a month during one year.

As the result, quality of this ultra underground water was higher concentration than ordinary ground water in the shallow layers, and belonged to $\mathrm{NaCl}$ type or $\mathrm{NaCl}+\mathrm{NaHCO}$ type. According to the results of Tritium concentration in this water, the $\mathrm{NaCl}$ component in this water was suggested not to originate from recent sea water but from fossil water.

The amounts of Radon in the ultra underground water were excesivly higher level than those level which was calculated from radioactive equilibrium with Radium, and therefor it was suggested that Radon was supplied from the basements.

Results of the continuous observation of one well were that water quality was stable and did not change during one year and also Radon contents were unchanged. This suggested that the basements around this well were unchanged.
\end{abstract}

\section{要 旨}

濃尾平野の地下には厚さ $1,500 \mathrm{~m}$ 以上及ぶ堆積層が厚く堆積しており，その下部に $50^{\circ} \mathrm{C}$ 前後の高 温の超深層地下水が存在する。

この超深層地下水の水質とラドン濃度の時期的変動を知る目的から，木曾川左岸の愛知県側にある 
11本の井戸について水質調査を行い，またこの中の 1 井については，水質とラドンについて 1 年間に 亘って連続観測を試みた。

その結果, 超深層地下水の水質はこの平野の浅層部の地下水よりも高濃度で, その水質組成は $\mathrm{NaCl}$ 型または $\mathrm{NaCl}+\mathrm{NaHCO}_{3}$ 型であった。そして，地下水中のトリチウム濃度から，地下水中の $\mathrm{NaCl}$ 成分は現在の海水によるものではなく，むしろ化石水に由来すると考えられた。

地下水中のラドンはラジゥムとの放射平衡量に比べて非常に多く，ラドンが基盤から供給されてい ることを示した。

連続測定の結果， 1 年間に亘って水質成分飞変動は認められず，安定した地下水であることがわか った。地下水中のラドン濃度に変動が認められなかったことから, 附近の地下の基盤に変動がなかっ たものと推定される。

\section{1. はじめに}

濃尾平野の地下には厚さ $1,500 \mathrm{~m}$ 以上に执よび沖積層, 洪皘層, 第三紀層の際, 砂, シルト, 粘土 より成る堆積層が厚く堆積しており, その堆積層の下部に高温の超深層地下水が存在し, その範囲は 木曾川，長良川，揖斐川の流域を中心として，愛知県，岐阜県，三重県にまたがっているとされてい る ${ }^{1-4)}$ 。そして現在までに約 30 本以上の $1,000 \mathrm{~m}$ 以深のさく井が行なわれ，その $50^{\circ} \mathrm{C}$ 前後の高温の地 下水が温泉として利用されている。

さて最近, 地下水中のラドン濃度の変動により, 地殼変動の手掛かりをつかむらとする研究が脇田 $5^{5-7)}$ によって行なわれている。濃尾平野の超深層地下水は比較的基盤岩に近い所から由来している と思われるので，その地下水の水質を地殼変動の指標として用い得る可能性が期待される。

そこで, 昭和 42 年以来現在までに木曾川左岸の愛知県側に堀られた $1,000 \mathrm{~m}$ 以深の 15 本の井戸のら ち，11本について水質の調査を行ならとともに，その中の 1 本について予備的調査として，地下水中 のラドン濃度の変動を知る目的で，比較的基盤に近いと思われる井戸を用いて，1年間に亘って各月 1 回ずつ連続して測定を行なってみた。

\section{2. 調查方法}

\section{1 調查地点}

調査の対象とした超深層地下水のさく井位置（温泉の源泉位置）を図一 1 に示したが，以下，図括 よび表中の符号は次の井戸を示す。
A 1-1 大名古屋温泉
I $1-1$ 尾張温泉・ 1 号井
I $1-2$ " 2 号井
I $1-3$ " 3 号井
I $2-1$ 飛島温泉・ 1 号井
I $2-2$ " 2 号井
I 3-1 永和温泉・ 1 号井
I $3-2$ " 2 号井

I $4-1$ 弥富温泉 


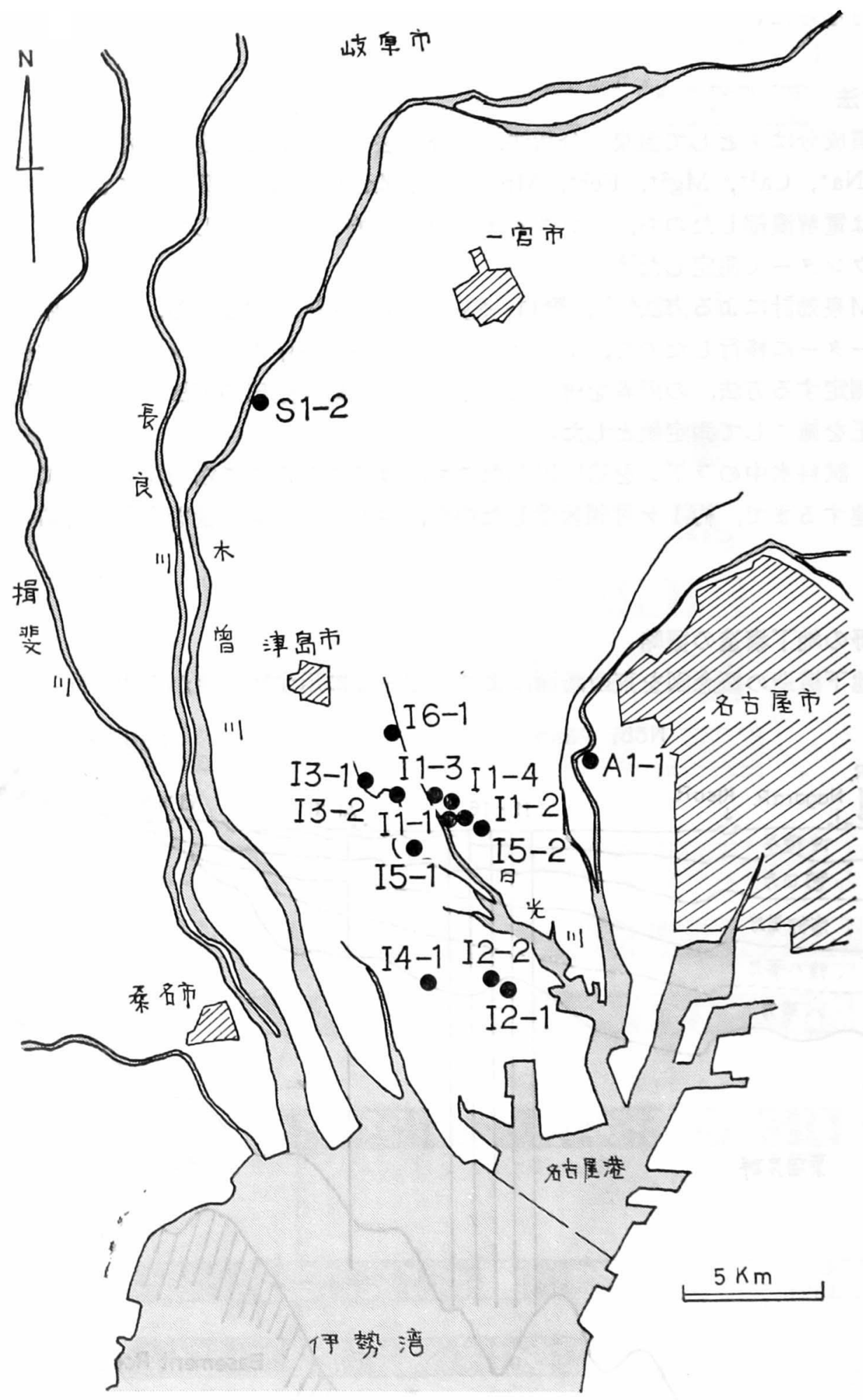

図一 1 超深層地下水の採水地点

I $5-1$ 富吉温泉

S $1-2$ 祖父江温泉

いずれも現在，温泉として利用されているものを選んだ。な括，祖父江温泉（S 1-2）について 
は連続測定を行なった。

\section{2 測定方法}

一般的な水質成分は主として温泉小分析法，中分析法9)に準じて測定を行なったが，pH はがラス 電極法, $\mathrm{K}^{+}, \mathrm{Na}^{+}, \mathrm{Ca}^{2+}, \mathrm{Mg}^{2+}, \mathrm{Fe}^{2+}, \mathrm{Mn}^{2+}, \mathrm{Cu}, \mathrm{Zn}, \mathrm{Cd}$ は原子吸光法により測定を行なった。

トリチゥムは電解濃縮したのち, インスタゲルをシンチレーターとして, ロウバック液体シンチレ ーション・カウンターで測定した ${ }^{10)}$ 。

ラドンは I M泉効計による方法9) と, 野ロ一脇田の方法 ${ }^{11,12)}$, すなわち, 試料水中のラドンをトル エンシンチレーターに移行したのち，トルエンシンチレーター中のラドンを液体シンチレーション・ カウンターで测定する方法，の両者を併せて行なった。野口一脇田の方法の回収率は75\%であった13) ので，その補正を施こして測定值とした。

ラジウムは，試料水中のラドンを追い出したのち，ガラスびん中に密封状態にして， ${ }^{226} \mathrm{Ra}-{ }^{222} \mathrm{Rn}$ の放射平衡に達するまで; 約 1 ケ月間放置したのち, 生じたラドンの量を上記の野口一脇田の方法で 測定した。

\section{3. 濃尾平野の地下構造の概略}

濃尾平野の地下構造の概念図を東西断面により，図一 2 に示す ${ }^{8)}$ 。東から西へ向って傾斜する基盤 Nöbi Plain

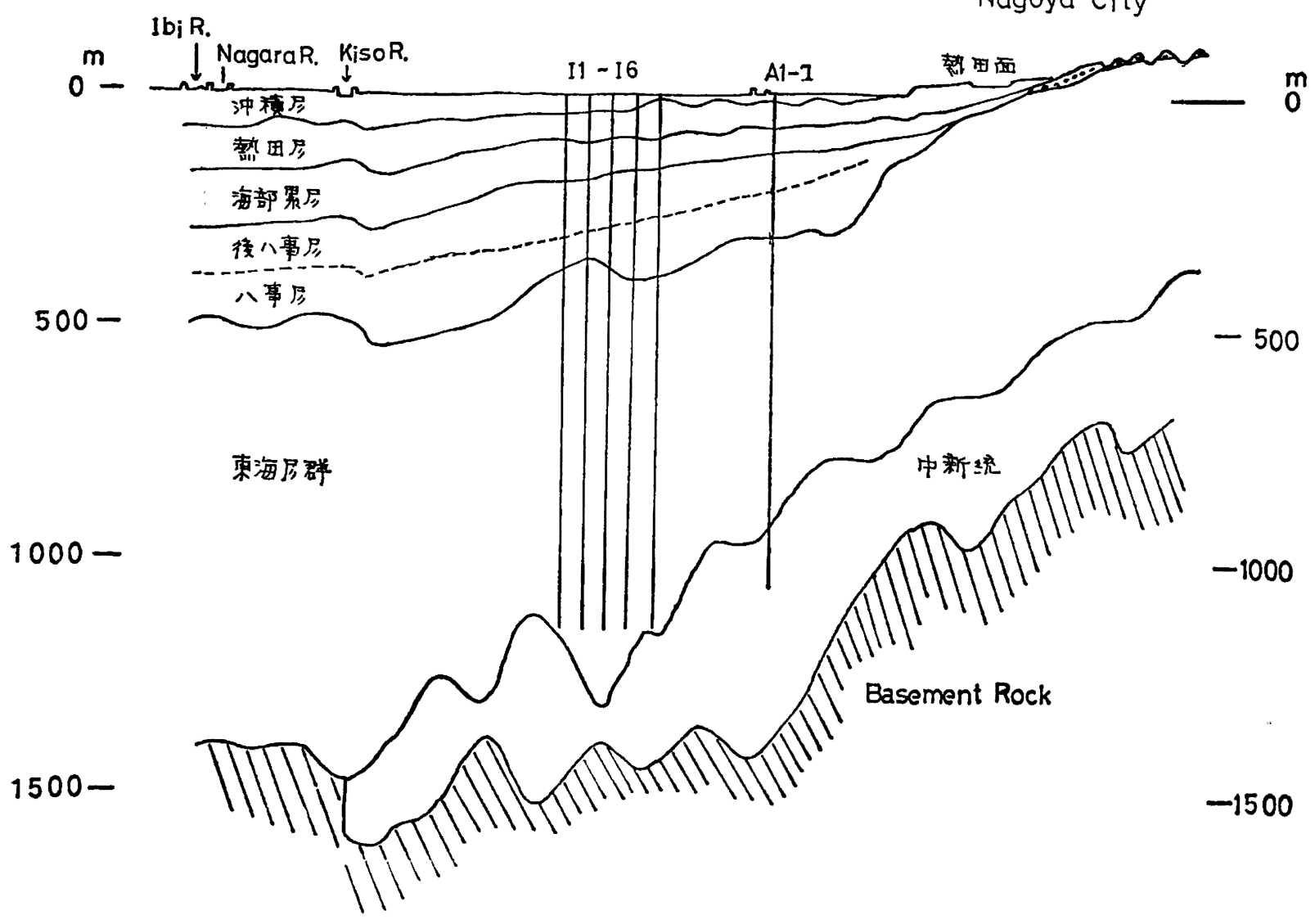

図一２地下構造の概念図 
$\widehat{\xi}^{\circ} \stackrel{\circ}{\circ}$

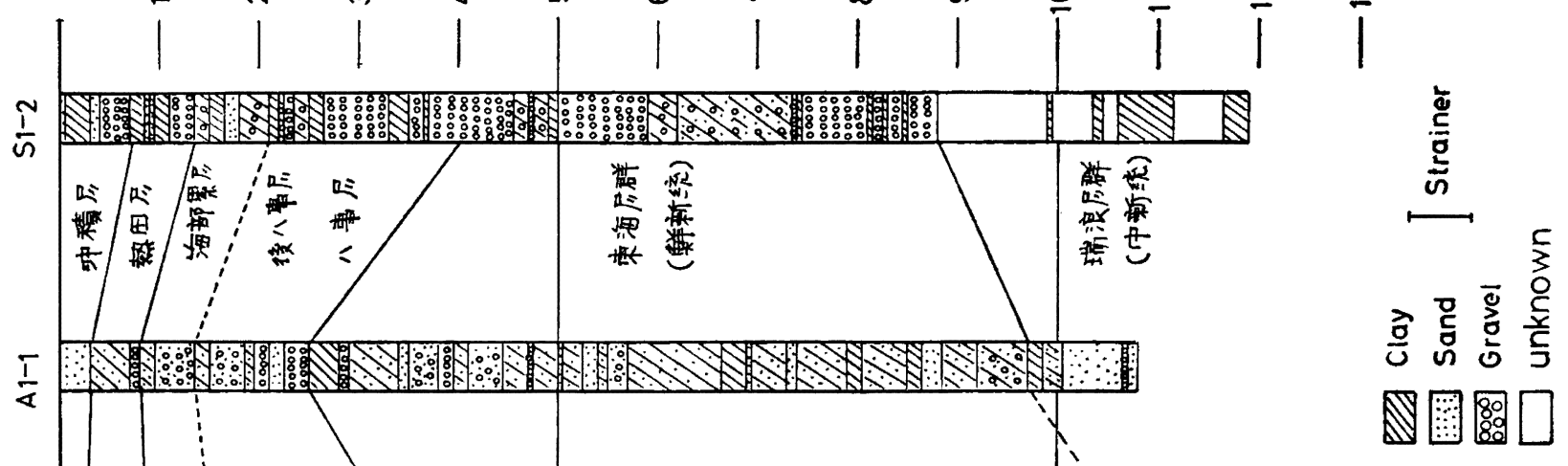

กิ in

乞́

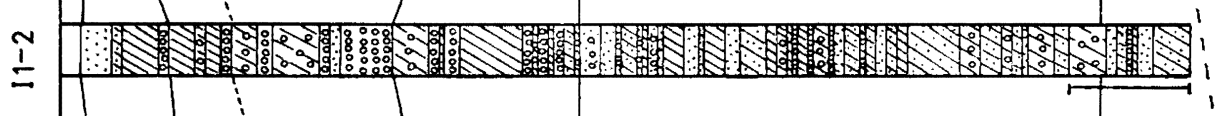

I

1 -

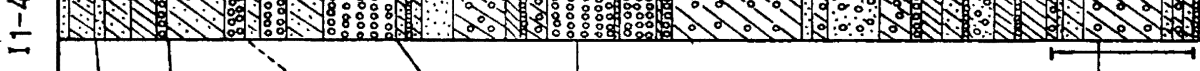

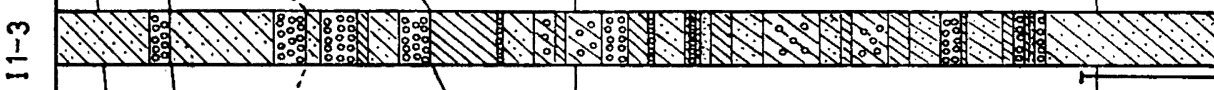

$\frac{1}{2}$

T 1 -

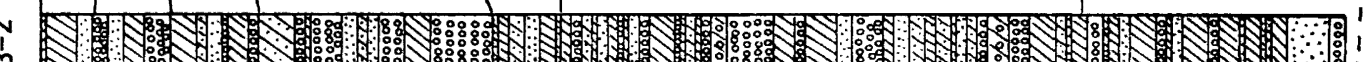

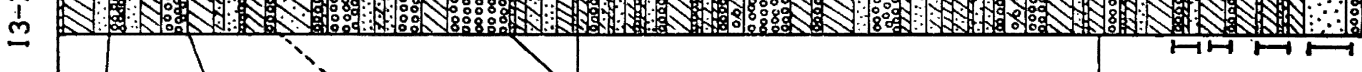

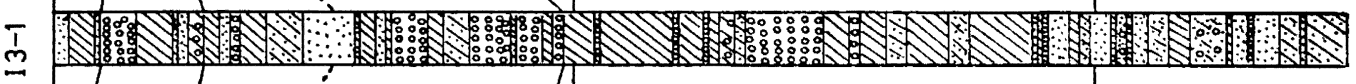
2.:

$\stackrel{1}{\stackrel{1}{\longrightarrow}}$

1.2.

$\stackrel{1}{\sim}$

A

1

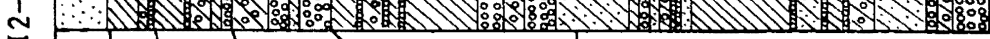

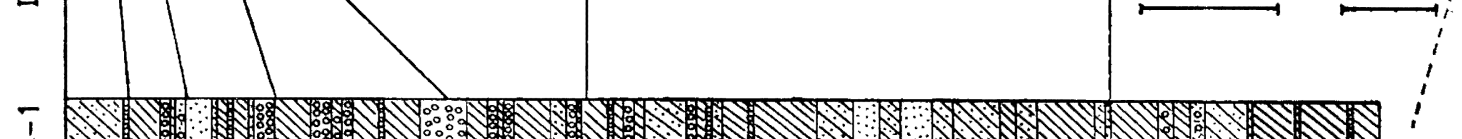

j

要

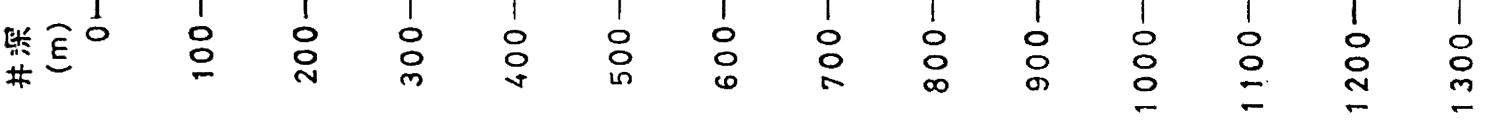


の上に, 磷, 砂, シルト, 粘土から成る堆積層が繰り返して厚く堆積しており, その最深部において は 1,300 m以上の厚さに及んでいる。さく井は殆んどのものが東海層群の中に打ち込まれて拈り，一 部のるのが中新統にまで及んでいる。

調査を行なった井戸および今回の調査対象から除外した一部の井戸（I 1-4， I 5-2， I 61）の柱状図を図一 3 亿示す。柱状図からみられる層序は, 上部から沖積層が約 $50 \mathrm{~m}$ 位まで薄く被っ て扮り，洪積層が300〜 500m位にあり，その下に鮮新統の東海層群が約 1,000 m位まで続く。ストレ 一ナーの位置からみて, 殆んどの井戸がこの東海層群の下部層から揚水していることが知られる。最 下部に海成の中新統端浪層群が $900 \mathrm{~m}$ 以深に一部みられる。

\section{4. 超深層地下水の水質上の特徽}

地下水の水質成分の測定結果を表一 1 に示す。表中，祖父江温泉（S 1-2）については年間の湘 定値の平均を記してある。

\section{1 水質の概略}

外観は殆んど無色澄明であり，塩味を示す祖父江温泉および微に塩味を示す大名古屋温泉（A 1 -

1）を除いて，何れも微に硫化水素臭を示す。

水温は祖父江温泉の $27.7^{\circ} \mathrm{C}$ と言ら微温を除いて, $42.3 \sim 55.1^{\circ} \mathrm{C}$ (平均 $49.7^{\circ} \mathrm{C}$ ) と高温である。 地下增温率との関係については既に述べだ) ので省略する。

祖父江温泉の水質は他のさく井と各種成分が著るしく異っているので，以下に述べる各成分の範囲 特よび平均值は祖父江温泉を除いて計算したものである。

$\mathrm{pH}$ は 7.8 8.4 (平均 8.0, S 1-2は7.5) であり, 何れも弱アルカリ性である。 $\mathrm{RpH}$ は 8.3〜 8.8 (平均 $8.7, \mathrm{~S} 1-2$ は 8.2) である。

電導度は $534 \sim 1,980 \mu \mho / \mathrm{cm}$ （平均 $1,150 \mu \mho / \mathrm{cm}, \mathrm{S} 1-2$ は $6,960 \mu \mho / \mathrm{cm}$ ）であり，何れも当 平野の浅層部の地下水に比べて高い。特に祖父江温泉で㥩るしく高くなっている。

溶存酸素は祖父江温泉を含めて, $0.0 \sim 0.6 \mathrm{mg} / l$ (平均 $0.2 \mathrm{mg} / l$ ) で, 测定誤差を考虑すると, 殆 んど含まれていないと言える。

遊離炭酸は $0.0 \sim 17.6 \mathrm{mg} / l$ (平均 $9.9 \mathrm{mg} / l, \mathrm{~S} 1-2$ は $13.5 \mathrm{mg} / l$ ) であり, 祖父江温泉と他の 地下水との差は認められない。

アンモニウムイオンは $0.35 \sim 1.74 \mathrm{mg} / l$ (平均 $0.99 \mathrm{mg} / l, \mathrm{~S} 1-2$ は $3.81 \mathrm{mg} / l$ ) であり, 祖父江 温泉では可成り高い。

カリウムイオンは $3.1 \sim 9.0 \mathrm{mg} / l$ (平均 $5.8 \mathrm{mg} / l, \mathrm{~S} 1-2$ は $14.0 \mathrm{mg} / l$ ) であり, 祖父汇温泉が 高い。何れる浅層部の地下水に比べて高くなっている。

ナトリウムイオンは $110 \sim 376 \mathrm{mg} / l$ (平均 $222 \mathrm{mg} / l, \mathrm{~S} 1-2$ は $1,070 \mathrm{mg} / l$ ) であり, 祖父江温 泉では著しく高く，また後述の塩素イオンと同様に浅層部の地下水に比べて高濃度である。

カルシゥムイオンは $3.5 \sim 30.6 \mathrm{mg} / l$ (平均 $15.3 \mathrm{mg} / l, \mathrm{~S} 1-2$ は $271 \mathrm{mg} / l$ ) で, 祖父江温泉が 著しく高い。

マグネシウムイオンも $0.6 \sim 4.3 \mathrm{mg} / l$, （平均 $1.6 \mathrm{mg} / l ， \mathrm{~S} 1-2$ は $60.7 \mathrm{mg} / l$ ）で, 祖父江温泉 が著しく高い。

第 1 鉄イオンは $0.05 \sim 0.35 \mathrm{mg} / l$ (平均 $0.22 \mathrm{mg} / l, \quad \mathrm{~S} 1$ - 2 は $0.22 \mathrm{mg} / l$ ) であり，祖父江温泉 


\begin{tabular}{|c|c|c|c|c|c|c|c|c|c|c|c|}
\hline$\frac{i}{n}$ & 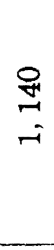 & $\begin{array}{l}\dot{\infty} \\
\dot{10} \\
i_{0} \\
\tilde{N} \\
\dot{\square} \\
\dot{B}\end{array}$ & $\tilde{\mathrm{N}}$ & 品 & 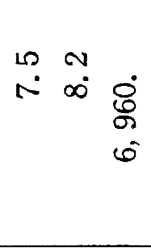 & $O \square$ & $\begin{array}{ll}0 & 10 \\
0 & \stackrel{9}{7}\end{array}$ & 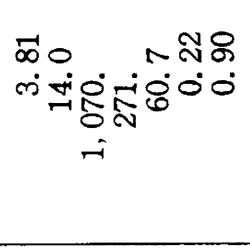 & 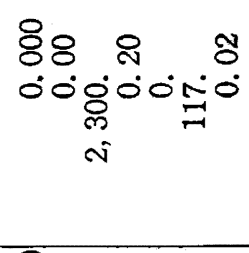 & นั & $\begin{array}{lll} & -1 & 8 \\
0 & 0 & 0\end{array}$ \\
\hline î & $\begin{array}{l}\text { ָ̃ } \\
-i\end{array}$ & $\begin{array}{l}\stackrel{g}{-1} \\
\ddot{1} \\
\dot{8}\end{array}$ & $\begin{array}{l}\infty \\
\dot{\varphi} \\
\dot{్}\end{array}$ & & $\begin{array}{lll}\infty & \infty & \\
& \infty & \dot{0} \\
& & 0 \\
& & 0 \\
& & \\
& & \\
& \end{array}$ & $\triangleleft$ & $\begin{array}{ll}N & m \\
0 & \stackrel{0}{0}\end{array}$ & 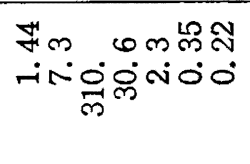 & 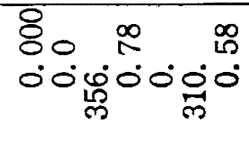 & ஸे & $\begin{array}{lll} & 8 & 8 \\
0 & 0 & 0\end{array}$ \\
\hline$\stackrel{I}{ \pm}$ & $\begin{array}{l}\text { ڤ్ } \\
\text { N } \\
\text { - }\end{array}$ & $\stackrel{7}{\ddot{1}}$ & 물 & $\begin{array}{l}\dot{8} \\
\dot{H}\end{array}$ & $\stackrel{+1}{\infty} \infty \underset{\infty}{\infty} \underset{\infty}{\stackrel{N}{\infty}}$ & $\triangleleft$ & $\begin{array}{ll}0 & 0 \\
0 & 0\end{array}$ & 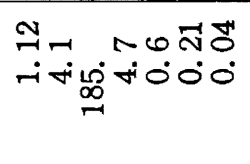 & $\begin{array}{l}88 \text { R } \\
\text { 000 }\end{array}$ & $\stackrel{m}{\mathscr{y}}$ & $\begin{array}{lll}8 & 8 & 8 \\
0 & 0 & 0\end{array}$ \\
\hline$\prod_{m}^{N}$ & 俑 & $\begin{array}{l}m \\
\ddot{1} \\
\dot{0}\end{array}$ & 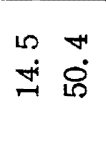 & 官 & 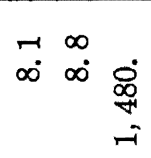 & $\triangleleft$ & $\begin{array}{ll}0 & 0 \\
0 & 0\end{array}$ & 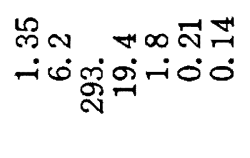 & 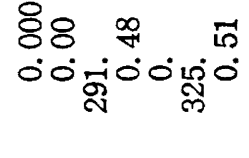 & $\ddot{\not ̈}$ & $\begin{array}{lll}-1 & 8 & 8 \\
0 & 0 & 0\end{array}$ \\
\hline $\mathfrak{m}_{m}^{T}$ & $\begin{array}{l}\text { ্ָ } \\
\text {-i }\end{array}$ & 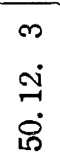 & $\stackrel{\sim}{\check{\infty}}$ & $\begin{array}{l}\dot{8} \\
\text { i. }\end{array}$ & $\begin{array}{ccc}0 & \infty & \\
\infty & \infty & \dot{0} \\
& & \\
& & 0 \\
& & \\
& & -1\end{array}$ & $\triangleleft$ & $\stackrel{m}{0} \underset{-}{0}$ & 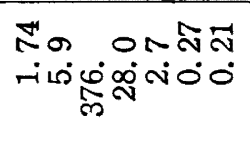 & 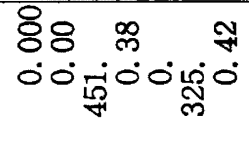 & $\stackrel{\infty}{\mathscr{y}}$ & $\begin{array}{lll}8 & 8 & 8 \\
0 & 0 & 0\end{array}$ \\
\hline$\stackrel{N}{\sim}$ & $\stackrel{m}{m}$ & $\begin{array}{l}\stackrel{2}{2} \\
\stackrel{\sim}{-1} \\
\stackrel{8}{8}\end{array}$ & $\stackrel{\sim}{-}$ & $\stackrel{-}{6}$ & 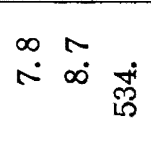 & & $\stackrel{\circ}{\circ}$ & 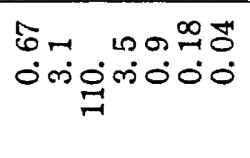 & 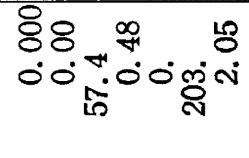 & $\stackrel{\infty}{\hat{\kappa}}$ & $\begin{array}{lll}8 & 8 & 8 \\
0 & 0 & 0\end{array}$ \\
\hline 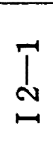 & $\begin{array}{l}\text { 怘 } \\
\text { - } \\
-1\end{array}$ & $\begin{array}{l}\stackrel{2}{8} \\
\dot{7} \\
\ddot{8}\end{array}$ & 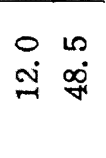 & & $\begin{array}{lll}0 & 0 & \\
& \infty & \dot{N} \\
& & -1 \\
& & -1\end{array}$ & & $\begin{array}{l}0 \\
0\end{array}$ & 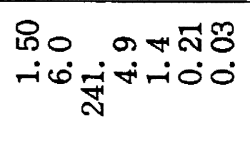 & 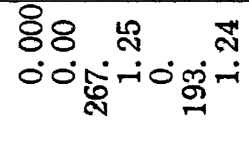 & ஜீ. & $\begin{array}{lll}8 & 5 & 8 \\
0 & 0 & 0\end{array}$ \\
\hline$\stackrel{p}{a}$ & $\stackrel{\vec{\Xi}}{=}$ & $\begin{array}{l}\stackrel{9}{2} \\
\dot{z} \\
\dot{8}\end{array}$ & $\begin{array}{lc}\infty & \sim \\
\stackrel{m}{\rightarrow} & \leftarrow\end{array}$ & & $\stackrel{\infty}{\sim} \underset{\infty}{0}$ & $\triangleleft$ & $\ddot{0} \stackrel{\sim}{\sim}$ & 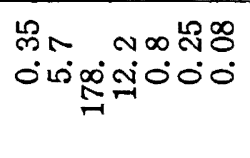 & 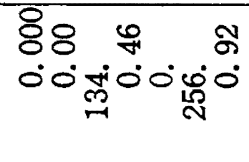 & $\begin{array}{l}0 \\
\text { ช் }\end{array}$ & 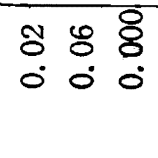 \\
\hline$\stackrel{\uparrow}{-1}$ & $\begin{array}{l}8 \\
0 \\
-1\end{array}$ & $\begin{array}{l}\infty \\
\stackrel{1}{1} \\
\ddot{1} \\
\dot{8}\end{array}$ & $\begin{array}{ll}\infty & \sigma \\
\dot{g} & \dot{\sigma}\end{array}$ & & $\ddot{\infty} \stackrel{\infty}{\infty}$ & $\triangleleft$ & $\begin{array}{l}0 \\
0 \\
0\end{array}$ & 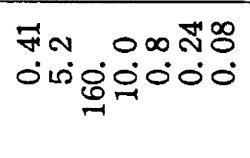 & 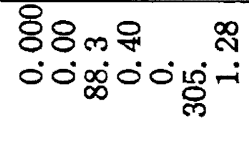 & $\stackrel{-}{\infty}$ & $\begin{array}{lll}8 & 8 & 8 \\
0 & 0 & 0\end{array}$ \\
\hline$\stackrel{T}{a}$ & $\begin{array}{l}\hat{8} \\
-i\end{array}$ & $\begin{array}{l}\stackrel{\infty}{\sim} \\
\dot{1} \\
\dot{8}\end{array}$ & $\begin{array}{l}\infty \\
\dot{\sim} \\
\dot{\sim}\end{array}$ & & $\stackrel{\infty}{\infty} \stackrel{\infty}{\infty}^{\infty}$ & $\triangleleft$ & $\begin{array}{ll}m & 0 \\
0 & \stackrel{1}{1}\end{array}$ & 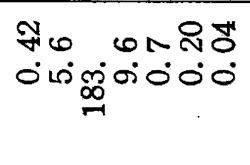 & $\begin{array}{l}88 \text { m } \\
00 \text { స్తి }\end{array}$ & $\begin{array}{l}10 \\
80\end{array}$ & $\begin{array}{lll}8 & 8 & 8 \\
0 & 0 & 0\end{array}$ \\
\hline$\frac{7}{4}$ & $\begin{array}{l}L_{0}^{\infty} \\
0 \\
-1\end{array}$ & $\begin{array}{l}\stackrel{m}{1} \\
\stackrel{-1}{-1} \\
\dot{8}\end{array}$ & $\begin{array}{l}m \\
m \\
m \\
\sim\end{array}$ & $\ddot{8}$ & 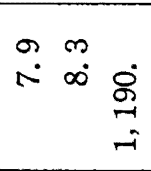 & 0 & $\stackrel{N}{0} \stackrel{m}{*}$ & 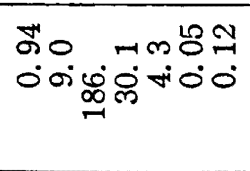 & 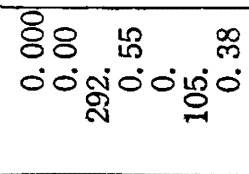 & $\begin{array}{l}\text { م } \\
\text { लें }\end{array}$ & $\begin{array}{lll}8 & 8 & 8 \\
0 & 0 & 0\end{array}$ \\
\hline$\dot{z}^{\circ}$ & हु & 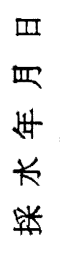 & 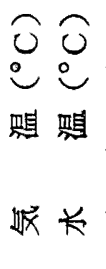 & 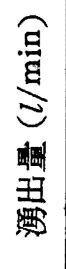 & 票䆓 & 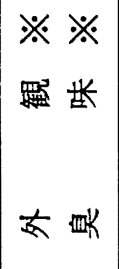 & 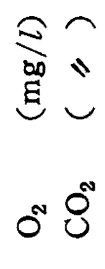 & 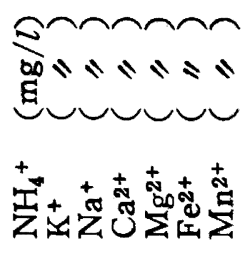 & ヘッミงーง & 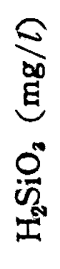 & 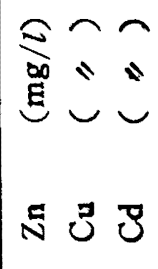 \\
\hline
\end{tabular}


他の地下水とに差は認められない。

マンガンイオンは $0.03 \sim 0.22 \mathrm{mg} / l$ (平均 $0.10 \mathrm{mg} / l, S 1-2$ は $0.90 \mathrm{mg} / l$ ) であり, 祖父江温 が可成り高い。

亜硝酸オインは祖父江温泉も含めて, 全て $0.000 \mathrm{mg} / l$ である。

硝酸イオンも祖父江温泉を含めて，全て $0.00 \mathrm{mg} / l$ である。

塩素イオンは，前述のナトリウムイオンと同様にこの超深層地下水の特徵を最もよく現わして扰 り, その濃度は $57.4 \sim 451 \mathrm{mg} / l$ (平均 $219 \mathrm{mg} / l, \mathrm{~S} 1$-2は $2,300 \mathrm{mg} / l$ ) であり, 浅㬝部の地下水 （深さ約 $50 \mathrm{~m}$ の第 1 帯水層の平均濃度 $11.7 \mathrm{mg} / l$, 深さ約 $190 \mathrm{~m}$ の第 2 帯水層の平均濃度 $2.3 \mathrm{mg}$ (l) ${ }^{14)}$ 飞比べて，相当に高く，特に祖父江温泉では著しく高濃度である。

弗素イオンは $0.34 \sim 1.25 \mathrm{mg} / l$ (平均 $0.59 \mathrm{mg} / l, S 1-2$ は $0.20 \mathrm{mg} / l$ ) であり, 祖父江温泉がや や低い值を示す。

硫酸イオンは祖父江温泉を含めて，全て $0 \mathrm{mg} / \mathrm{l}$ であり，その臭味よりして硫化水素の存在が認め られる。

ヒドロ炭酸イオンは $105 \sim 325 \mathrm{mg} / l$ (平均 $259 \mathrm{mg} / l, \quad \mathrm{~S} 1$-2は $117 \mathrm{mg} / l$ ) であり, 祖父江温泉と の差は認められない。

ヒドロ燐酸イオンは $0.38 \sim 2.05 \mathrm{mg} / l$ (平均 $0.92 \mathrm{mg} / l, \quad \mathrm{~S} 1-2$ は $0.02 \mathrm{mg} / l$ ) であり, 祖父江温 泉が非常に低い值を示す。

メタ珪酸は 30.3 $69.5 \mathrm{mg} / l$ (平均 $48.6 \mathrm{mg} / l, \mathrm{~S} 1$ - 2 は $25.2 \mathrm{mg} / l$ ) であり, 祖父江温泉に括 いてやや低い。

亜鉛は $0.00 \sim 0.02 \mathrm{mg} / l$ (平均 $0.00 \mathrm{mg} / l$ ), 銅は $0.00 \sim 0.06 \mathrm{mg} / l$ (平均 $0.01 \mathrm{mg} / l$ ), カドミウ ムは全て $0.000 \mathrm{mg} / l$ である。

トリチウム, ラドン, ラジゥムについては後に述 べる。

\section{2 水質の組成}

全般的に超深層地下水の水質は，この平野の浅層 部の地下水 ${ }^{14},{ }^{15)}$ に比べて濃度がやや高く, 特に祖 父江温泉に扣いては著るしく高濃度である。しかも 図一4にそれぞれの地下水について，全陰イオン中 飞占める塩素イオンの割合と全陽イオン量との関係 を示すが，図から見られる如く，水質中に占める塩 素イオンの割合が高い地下水ほど，全イオンの量は 多くなっており, 塩素イオンによって水質濃度が高 められていることがわかる。

図一 5 亿地下水の水質組成を示す。祖父江温泉, 大名古屋温泉は $\mathrm{NaCl}$ 型の組成であり, 他は $\mathrm{NaCl}$ $+\mathrm{NaHCO}_{3}$ 型の組成であることがわかる。水質濃度 が最も高い祖父江温泉は海水の組成比汇非常に近く, 濃度が最も低い飛島温泉・2 号井 (I 2-2) は海

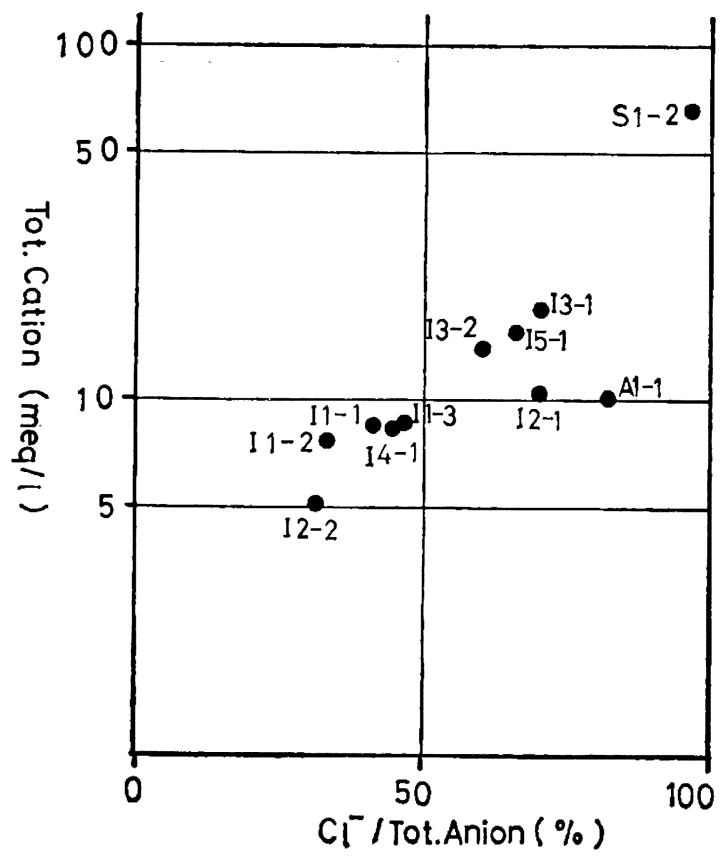

図一 4 全陰イオン中に占める塩素イオンの 割合と全陽イオン量の関係 


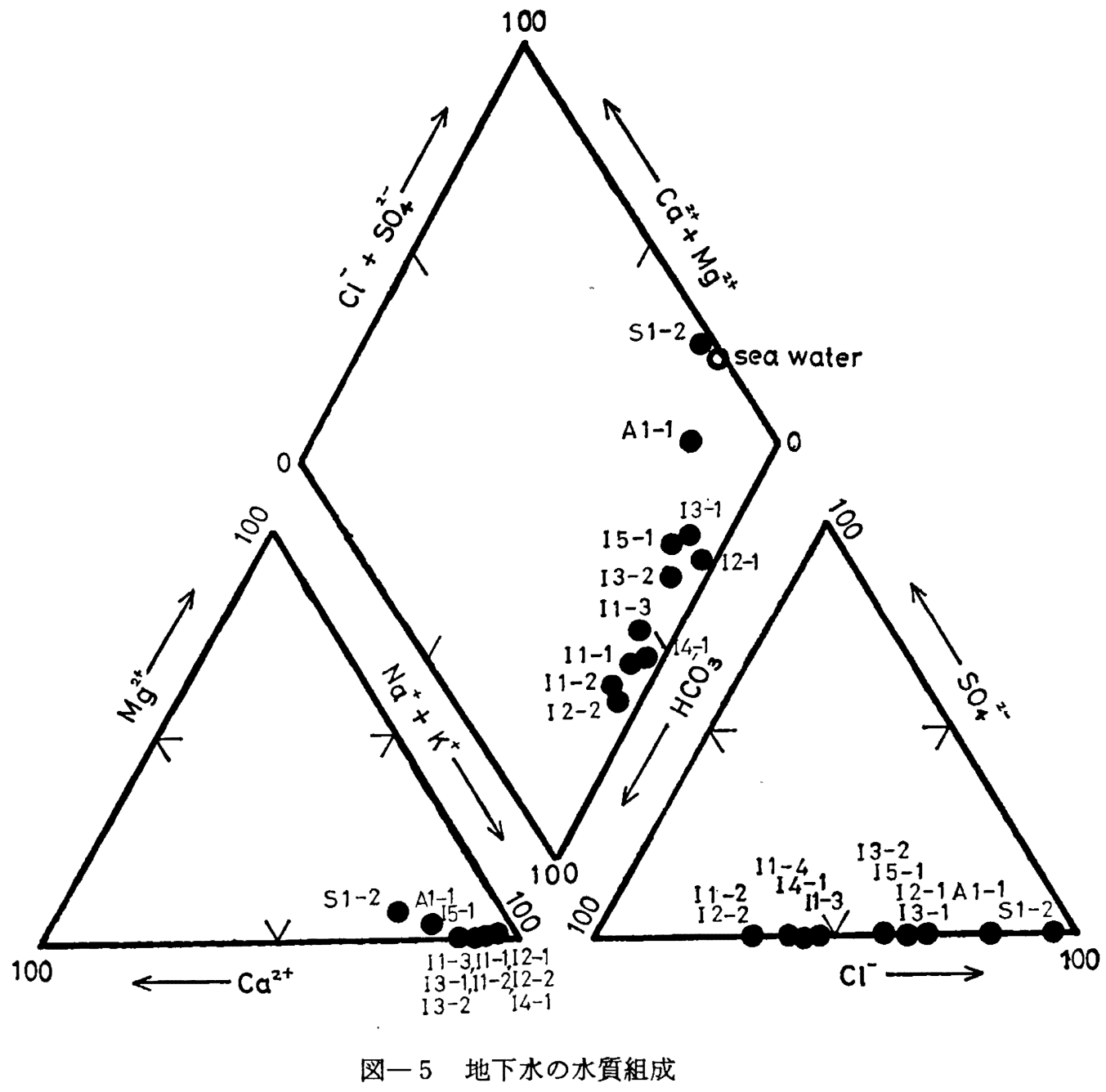

水の組成比からは最も㕍れており，浅層部の地下水の進化した組成 ${ }^{15)}$ に近く, $\mathrm{NaHCO}_{3}$ 型である。 他はこの両者の混合より成る中間型の組成である。

次湯イオンの主成分の割合を海水の組成と比較してみる。地下水中の塩素イオン量と海水の塩素 イオン量との比較から，海水が稀釈されたものとして，その際の海水の組成に対しての各成分の增減 率を次式により求めた。

$$
\begin{aligned}
\mathrm{rM}= & (\mathrm{M} / \mathrm{Cl}) \text { samp. } /(\mathrm{M} / \mathrm{Cl} l) \text { sea } \\
& \mathrm{rM}: \text { 海水の組成に対しての各成分の増減率 } \\
& \mathrm{M}: \text { 各成分の } \mathrm{meq} / l \\
& \mathrm{Cl}: \mathrm{Cl} l^{-} \text {の } \mathrm{meq} / l
\end{aligned}
$$

カリウム, ナトリウム, カルシウム, マグネシウム各イオンについての計算結果を表一 2 に示す。 カリウムイオンは, $\mathrm{rK}^{+}=0.3 \sim 2.9$ (平均 1.6) で, 祖父江温泉の 0.3 , 永和温泉・1号井 ( I 31) の 0.7 以外は増加している。

ナトリウムイオンは, $\mathrm{rNa}^{+}=0.8 \sim 3.5$ (平均 2.1 ) で, 祖父江温泉の 0.8 を除いて全て增加がみら れる。 
表一 2 主成分の増減率

\begin{tabular}{|c|c|c|c|c|c|}
\hline NO & $\mathrm{Cl}^{-1}(\mathrm{meq} / \mathrm{l})$ & $\mathrm{rK}^{+}$ & $\mathrm{rNa}^{+}$ & $\mathrm{rCa}^{2+}$ & $\mathrm{rMg}^{2+}$ \\
\hline Sea & 560. & & & & \\
\hline$A 1-1$ & 8.24 & 1.6 & 1.1 & 5.1 & 0.2 \\
\hline $11-1$ & 3.44 & 2.3 & 2.7 & 3.9 & 0.1 \\
\hline-2 & 2.49 & 2.9 & 3.3 & 5.6 & 0.2 \\
\hline-3 & 3.78 & 2.2 & 2.4 & 4.5 & 0.1 \\
\hline I 2-1 & 7.53 & 1.1 & 1.6 & 0.9 & 0.1 \\
\hline-2 & 1.62 & 2.8 & 3.5 & 3.1 & 0.2 \\
\hline $13-1$ & 12.72 & 0.7 & 1.5 & 3.1 & 0.1 \\
\hline-2 & 8.21 & 1.1 & 1.8 & 3.3 & 0.1 \\
\hline $14-1$ & 3.67 & 1.7 & 2.6 & 1.8 & 0.1 \\
\hline $15-1$ & 10.04 & 1.1 & 1.6 & 4.3 & 0.5 \\
\hline $\mid s 1-2$ & 64.9 & 0.3 & 0.8 & 5.8 & 0.4 \\
\hline
\end{tabular}

カルシウムイオンは, $\mathrm{rCa}^{2+}=0.9 \sim 5.8$ (平均3.8) で, 飛島温泉・1号井（I 2-1）の 0.9 を除 いて全て增加している。しかも他の成分に比べて, その增加率は最も高い。

マグネシウムイオンは, $\mathrm{rMg}^{2+}=0.1 \sim 0.5$ (平均 0.2 )で, 全て減少しており, その割合も非常に高 い。

平均して，地層からカリウム，ナトリウム，カルシウムが与兄られ，マグネシウムが䍘われた結果 となっている。南関東ガス田についての杉崎らの結果16) では，ナトリウムイオンが增加し，カリウ ム, カルシウム、マグネシウム各イオンが減少しているが, カリウム, カルシウムの場合にみられる この相違は地質の差異によるるのと思われる。特にこの地域の地下水にみられるカルシウムイオンの 著しい増加は，当平野の西側山地に露出がみられるが，古生層の石灰岩に起因すると思われる。

各成分間の增减率の相関をみてみると, $\mathrm{rK}^{+}$と $\mathrm{rNa}^{+}$との間傐い相関 $\left(r=0.903, \mathrm{rNa}^{+}=0.92 \times\right.$ $\mathrm{rK}^{+}+0.59$ ) が認められるが，他成分間には相関はみられない。 $\mathrm{rK}^{+}, \mathrm{rNa}^{+}$に相関が高いことから， カリウムとナトリウムは同じよらな挙動をしていることが知られる。

各成分の増減率と塩素イオン濃度との関係をみてみると, $\mathrm{rK}^{+}$との関係を図一 $5 \mathrm{~K}, \mathrm{rNa}^{+}$との関 俰を図一6に示す。 $\mathrm{rK}+$ の場合は $\gamma=-0.97, \mathrm{rNa}^{+}$の場合は $\gamma=-0.93$ で共に高い負の相関がみら れる。しかし， $\mathrm{rCa}^{2+}, \mathrm{rMg}^{2+}$ の場合には相関性は認められなかった。図一5，6からみられる如く， 塩素イオン濃度の高いすのは殆んど海水の比率に近いが塩素イオン濃度が低くなるにつれて $\mathrm{rK}^{+}$, $\mathrm{rNa}^{+}$は高くなって行く。このことは, 海水が $\mathrm{NaHCO}_{3}$ を主成分とする淡水により薄められて行くこ とを示唆する。すなわち, 海水の組成に最も近い祖父江温泉の水質 $(\mathrm{NaCl}$ 型) が, 塩素イオン濃度 


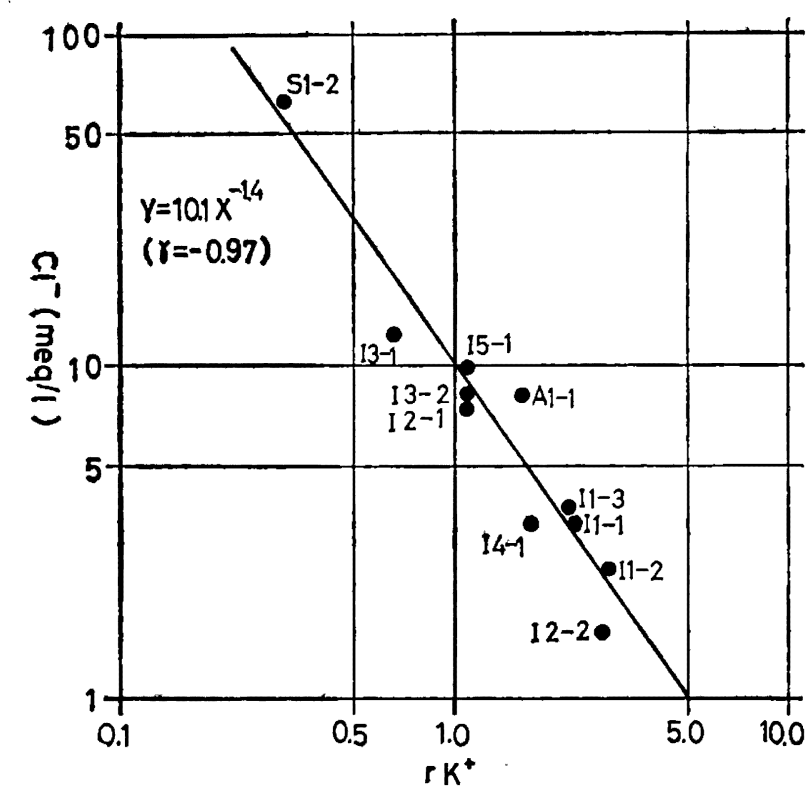

図一 6 カリウムイオンの増隇率と 塩素イオン量の関係

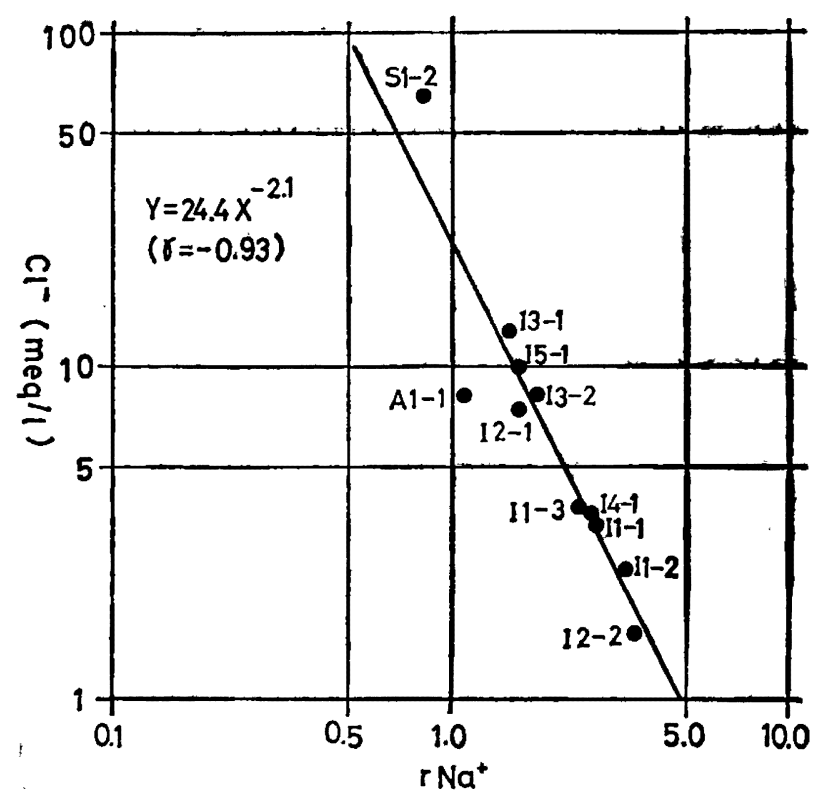

困一 7 ナトリウムイオンの増隇率と 塩素イオン量の関係

の最す低い飛島温泉・ 2 号井の水質（当平野の浅層部の地下水の水質飞最も近い, $\mathrm{NaHCO}_{3}$ 型）に上 って稀秎されて，これらの超深層地下水の水質組成がでさているものと思われる。

図一３に示したさく井柱状図からみて，地下帯水層の状態は比較的よく連絡が保たれているようで ある。上述の如く，水質濃度および組成声がみられるのは，図一 3 にストレーナーの位置が示して あるが，各井戸は数層の帯水層に亘って揚水を行なっている。各帯水層毎に水質が異なると思われる ため，それぞれの帯水層別の揚水量の違いによって，水質に差が出てくるすのであろら。

\section{5. 超深層地下水中のトリチウム濃度}

この超深層地下水中にみられる高濃度の成分が何に由来するかを知るるら一つの手掛かりとして, 地下水中のトリチウム濃度の測定を行ない，地下水の年代測定を試みた。測定結果を表一 3 に示す。

トリチウムによる地下水の年代測定は，過去の地表水のトリチウム濃度が充分に明らかにされてい ないため, まだ不確かではあるが,ここでは一応, 過去の地表水のトリチウム惯度が 10 T.U. であ ったとして計算を行なった。得られたトリチウム濃度の結果からは, 勿論昭和 29 年以降の核実験の影 響を受けていないそれ以前の水であることがわかる。計算の結果を表中の最右欄に示す。

表一 3 地下水中のトリチウム濃度

\begin{tabular}{|c|c|c|c|}
\hline NO & 採水年月 & ${ }^{3} \mathrm{H}$ 淡度(T.U.) & 年代 ( $\left.N_{0}=10 T . U . \varepsilon し \tau\right)$ \\
\hline $11-1$ & $48 / 3.49 \% 50$ & $0.0 \pm 1.7$ & $\infty$ 年 $(31-\infty)$ \\
\hline $13-1$ & $48.49 \% \cdot 50 /$ & $1.3 \pm 1.7$ & 36 年 $(21-\infty)$ \\
\hline S1-2 & $49 / 0.50 / 11$ & $0.6 \pm 1.7$ & 50 年 $(26 \sim \infty)$ \\
\hline
\end{tabular}


測定値の誤差を考慮すると，これらの値はむしろ心年前のものであると考光た方が良いよらであ り，これらの地下水中の $\mathrm{NaCl}$ 成分は，現在あるいは少なくとも昭和29年以降の海水によりもたらさ れたものではなく，かなり古いものであろうと考兄られる。むしろ，化石水に由来するものと考克た 方が適当であろら。

しかし，それを確かめるためには，トリチウムによる方法では限界的に不可能であるので，これに 代わる年代測定の方法を試みなければならない。そのためには木越 ${ }^{17)} の{ }^{234} \mathrm{U} /{ }^{238} \mathrm{U}$ による方法などが 適していると思われる。

\section{6. 超深層地下水中のラドン, ラジウム濃度}

地下水中のラドンの I M泉効計による測定值，液シン法による測定值括よびラジウムの測定值を表 -4 亿示す。両者の比較を図一 8 に示す。

ラドン濃度の I M 泉効計による測定值 $(\mathrm{Y})$ と液シン法による測定值 $(\mathrm{X})$ は, $\mathrm{Y}=1.15 \mathrm{X}-0.18$, $r=0.984$ で, 約 1 割の誤差範囲で一致し，液シン法が充分に実用され得ることが確かめられた。

地下水中のラドン濃度は, 祖父汇温泉の $19.6 \times 10^{-10} \mathrm{Ci} / l$ を除いて, $2.4 \sim 10.0 \times 10^{-10} \mathrm{Ci} / l$ （平均 $\left.4.2 \times 10^{-10} \mathrm{Ci} / l\right)$ であり，祖父江温泉のみが温泉法の規定 ${ }^{9}$ 飞適用し得るほどの量の高いラドン濃度 を示す。

ラジゥム濃度は, 祖父江温泉の $0.36 \times 10^{-10} \mathrm{Ci} / l$ を除いて, $0.00 \sim 0.09 \times 10^{-10} \mathrm{Ci} / l$ （平均 $0.04 \times$ $\left.10^{-10} \mathrm{Ci} / l\right)$ と非常に低い值であり，ラドンとの放射平衡量の約 $1 / 100$ の値である。

この結果は，地下水中のラドンは何れも，地下水中に溶在するラジウムに由来するもののみではな いと言える。ラドンの供給源としては，帯水層をなす地層をたは下部の基盤が考光られるが，この地 下水を包含する帯水層は鮮新統東海層群または中新統瑞浪層群の堆積層であり, これらの地層中に多 量のラジウムが存在するとは考兄難い。また，東海層群に帯水層をるつ井戸に比べて 瑞浪群に帯水 層をむつ井戸のラドン濃度が高いが, 東海層群の地層に比べて瑞浪層群の地層にラジウムの存在量が 多いとも考光難い。従って地下水中のラドンはその殆んど全てが帯水層以外の所から供給されてい

表一 4 地下水中のラドン, ラジウム濃度

\begin{tabular}{|c|c|c|c|}
\hline \multirow{2}{*}{ No } & \multicolumn{2}{|c|}{${ }^{222} \mathrm{Rn}\left(\times 10^{-10} \mathrm{Ci} / \mathrm{l}\right)$} & \multirow{2}{*}{${ }^{226} \mathrm{Ra}\left(\times 10^{-10} \mathrm{C} / \mathrm{l}\right)$} \\
\hline & 堔シン法 $(\mathrm{X})$ & 泉奻勀抾 $(Y)$ & \\
\hline $\mathrm{A} 1-1$ & 10.0 & 11.8 & 0.01 \\
\hline I1 - & 2.4 & - & 0.03 \\
\hline-2 & 3.6 & - & 0.09 \\
\hline-3 & 3.6 & 一 & 0.00 \\
\hline $12-1$ & 3.7 & - & 0.05 \\
\hline-2 & 4.1 & 4.0 & 0.00 \\
\hline I 3-1 & 2.8 & 3.1 & 0.03 \\
\hline-2 & 4.4 & - & 0.05 \\
\hline $14-1$ & 4.7 & 4.6 & 0.05 \\
\hline $15-1$ & 2.7 & - & 0.07 \\
\hline $51-2$ & 19.6 & 22.3 & 0.36 \\
\hline
\end{tabular}

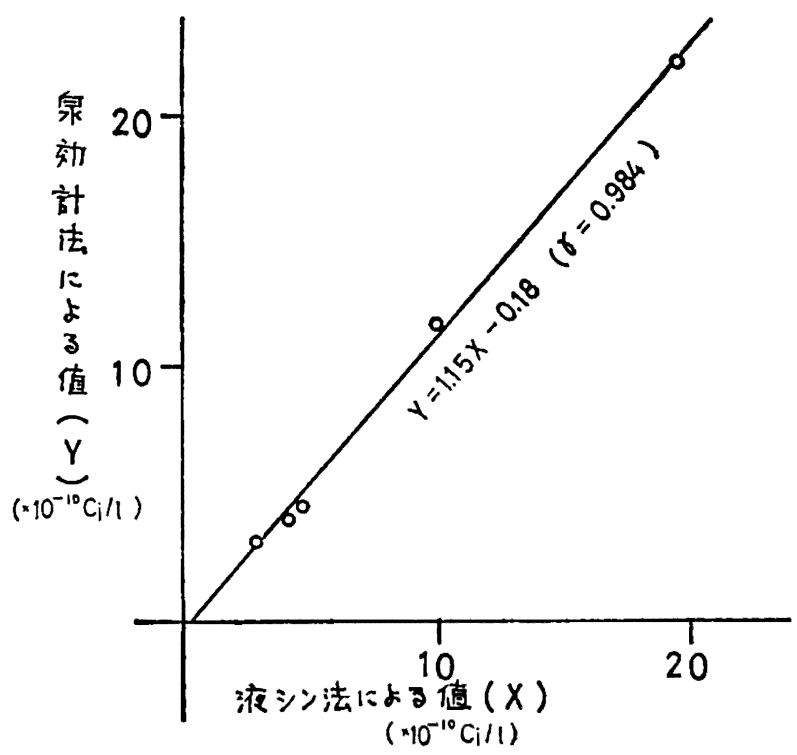

S $1-2$ の値は年間の平均値

図一 8 液シン法と泉効計法の比較 
る，すなわち当平野の基盤から供給されているものであることを示唆している。しかも，このことを 裏づける如く，帯水層の位置が中新統にまで及んで括り，最も基盤に近いと思われる祖父江温泉にお いて，ラドン濃度は最も高く，次に基盤に近いと思われる大名古屋温泉がそれに次ぐ濃度を示してい る。

\section{7. 地下水の水質成分およびラドン, ラジウム濃度の連続測定結果}

地下水中のラドン濃度の変動により, 地殼の変動を知ろらとする研究は最近よく行なわれている。 濃尾平野の超深層地下水のうちラドン濃度が最も高く，その水質 $(\mathrm{NaCl}$ 成分が高濃度である）お よび帯水層の位置（中新統瑞浪層群にまで及んでいる）からみても，基盤の影響をより多く受けてい ると思われる祖父江温泉を選んで，昭和50年 4 月〜 51年 3 月の 1 年間に亘って，各月 1 回ずつ，その 水質成分およびラドン, ラジウム濃度の測定を試みた。

測定結果を表一 5 に示す。水質の主成分およびラドン濃度の年間の推移の状熊を図一 9 に示す。各 成分の年間の変動率 $(\sigma / \overline{\mathrm{x}} \%)$ を図中の右側に示す。

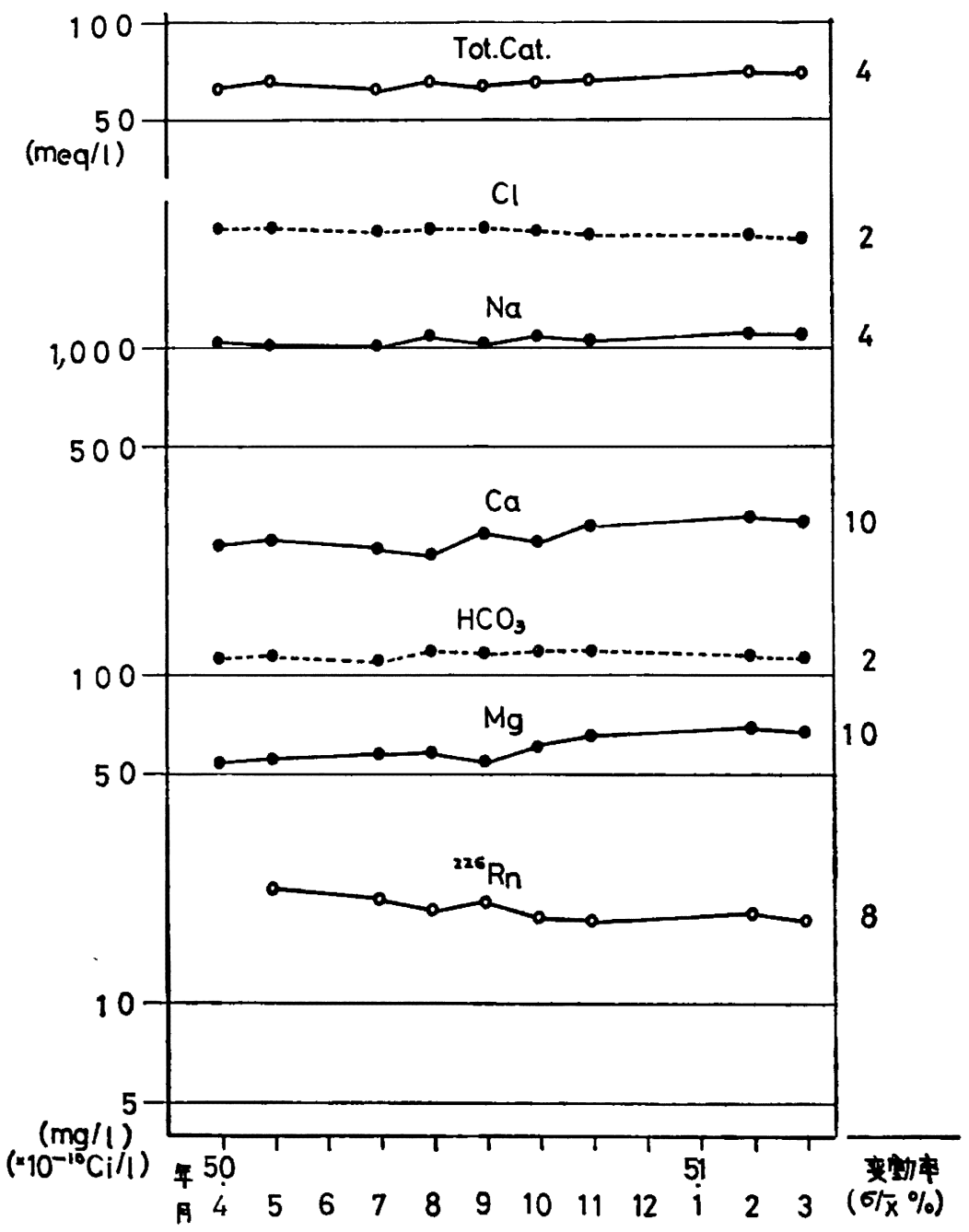

図一 9 水質の主成分およびラドン漊度の年間推移 
表一 5 地下水の水質成分およびラドン, ラジウム濃度の連続測定結果

採水年月日

\begin{tabular}{|l|l|l|l|l|l|l|l|l|l|l|l|l|} 
50. 4. 23 & 50. & 5.28 & 50. & 7.23 & 50. & 8.27 & 50. & 9.26 & 50.10 .22 & 50.11 .26 & 51.2 .25 & 51.3 .24
\end{tabular}

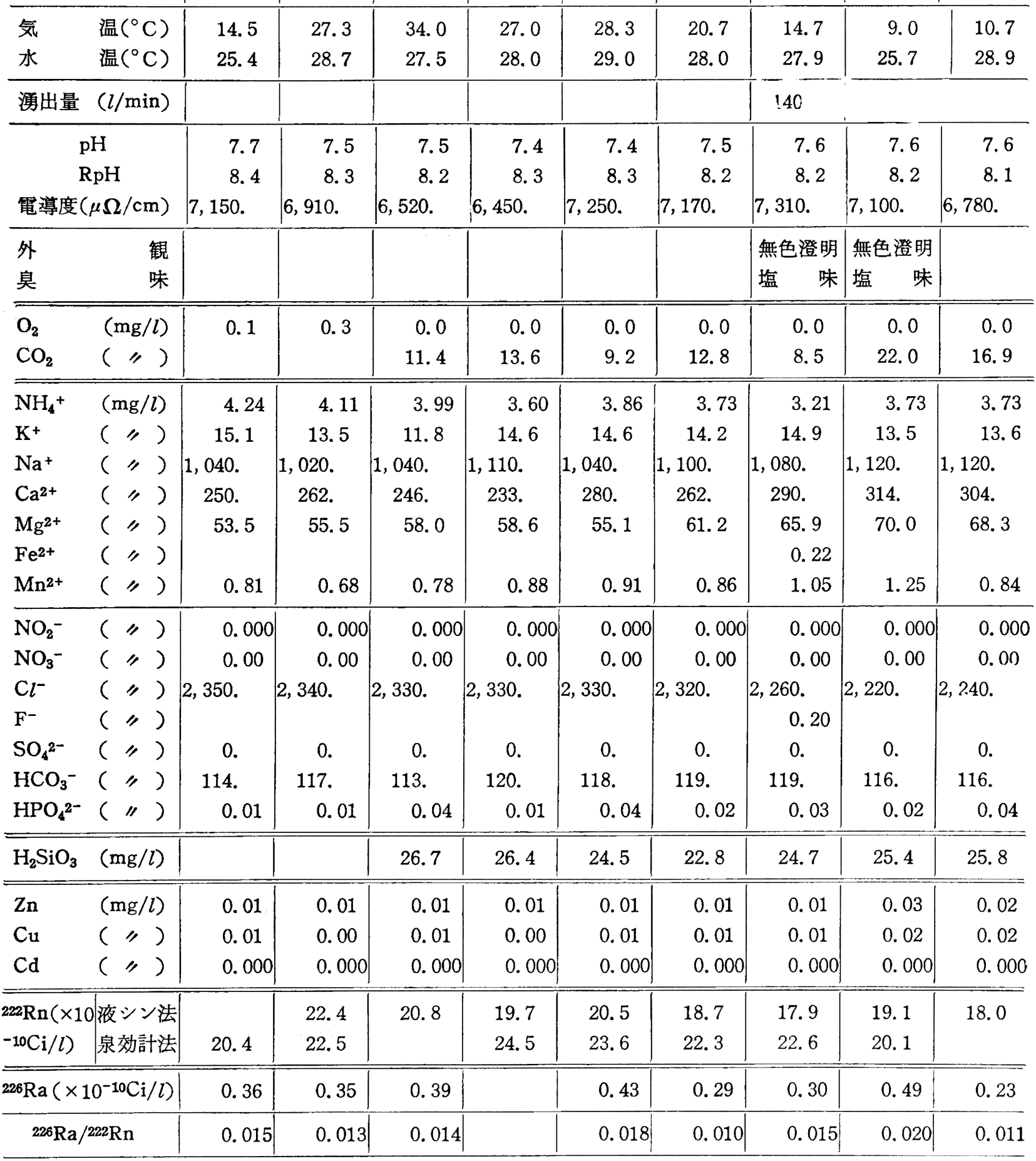

水質の主成分は，各成分について，2１0\%の変動率であり，殆んど変動がないと云觉る。図中， カルシウム，マグネシウムイオンの濃度は経時的にやや増加しているように見えるが，この期間の前 半の值と後半の値を比較してみたところ有意な差は認められなかった。この様に，水質的にも年間を 
通して殆んど変化のない安定した地下水である。これはトリチウムによる年代測定の結果から得られ た，古い水であると云う事実とすよく一致している。

次に，この様な安定した地下水へ基盤から絶えず供給されていると思われるラドンの量についてみ てみる。地下水中のラドン濃度は，液シン法による値の年間平均値 $19.6 \times 10^{-10} \mathrm{Ci} / l$, 变動率 $8 \%$ \%あ った。図一9にみられる如く，ラドン濃度は経時的にやや減少しているよ5に見える。この期間の前 半の值 $(\overline{\mathrm{x}}=20.9, \sigma=1.1)$ と後半の值（ $\overline{\mathrm{x}}=18.4 ， \sigma=0.6 ）$ を比較したところ有意な差が認められ た。然し，この測定方法の誤差 (約一割) を考慮すると，変動率の $8 \%$ はその範囲の中に含まれてし まうので, 経時的に減少していると云うわけにはいかない。むしろ年間を通して比較的安定している （但し変動率 $8 \%$ で）と云える。また，ラジウム濃度も $0.23 \sim 0.49 \times 10^{-10} \mathrm{Ci} / l$ （平均 $0.36 \times 10^{-10}$ $\mathrm{Ci} / l$ ) で, 殆んど変動はない。さらに Ra/Rnの值においても，0.010〜0.020（平均0.015）であり, 変動が殆んど認められない。

ラジウムがラドンとの放射平衡量に対して約 $1 / 100$ の量しか存在せず，地下水中のラドンが他から 供給されていることを示している。しかも，この基盤から由来すると考えられるラドンの供給量は， 地下水中のラドン濃度の変動率および $\mathrm{Ra} / \mathrm{Rn}$ 比の值の変動率からみて年間を通じて定常的であると 云光る。

タシケント地震（1966年 4 月26日）の例に見られるように ${ }^{18)}$ ，基盤からのラドンの供給量は基盤の 状態に作用されるはずであるから，この調查期間を通じて，祖父江温泉の附近の地下の基盤に変動が なかったものと推定することができる。

\section{8. 結 論}

濃尾平野の地下には厚さ $1,500 \mathrm{~m}$ 以上に及ぶ堆積層が厚く堆積しており，その下部に $50^{\circ} \mathrm{C}$ 前後の 高温の超深層地下水が存在する。

超深層地下水の水質はこの平野の浅層部の地下水に比べて濃度が高く，特に祖父江温泉においては 著るしく高濃度である。

その水質組成は, 祖父江温泉, 大名古屋温泉は $\mathrm{NaCl}$ 型の組成であり, 他は $\mathrm{NaCl}+\mathrm{NaHCO}_{3}$ 型の 組成である。塩素イオン量を基準にして海水の組成と比較すると，カリウム，ナトリウム，カルシウ ムイオンが増加し，マグネシウムイオンが減少している。各地下水の組成の差は，帯水層毎に異なる 水質組成の地下水を 2 層以上に亘って揚水しているためと思われる。

地下水のトリチウム濃度は非常に低く，その年代測定の結果から非常に古い地下水であると考えら れ，地下水中の $\mathrm{NaCl}$ 成分は現在の海水によりるたらされたるのではなく，化石水に由来すると考文 た方が適当であろら。

地下水中のラドンの測定において，液シン法による測定值はI M泉効計による測定值とよく一致 し，液シンによる方法が充分に実用され得ることが確かめられた。

地下水中のラドン濃度は, 祖父江温泉は $19.6 \times 10^{-10} \mathrm{Ci} / l$ と高い值を示すが, 他は $2.4 \sim 10.0 \times 10$ ${ }^{-10} \mathrm{Ci} / l$ (平均 $4.2 \times 10^{-10} \mathrm{Ci} / l$ ) と低い值である。一方, ラジウム濃度は, 祖父江温泉の $0.36 \times 10^{-10}$ $\mathrm{Ci} / l$ を除いて, $0.00 \sim 0.09 \times 10^{-10} \mathrm{Ci} / l$ (平均 $0.04 \times 10^{-10} \mathrm{Ci} / l$ ) と非常に低い值であり，ラドンとの 放射平衡量の約 $1 / 100$ であり，地下水中のラドンが他から供結されているものであることを示してい る。

この平野の超深層地下水のうち最も基盤の影響を受けていると思われる祖父江温泉について，昭和 
50年 4 月～51年 3 月に亘って連続測定を行なった。

水質の主成分は, 各成分について $2 \sim 10 \%$ 変動率で, 殆んど変動のない安定した地下水であると 云える。ラドン濃度については変動率 $8 \%$ で, やはり年間を通じてよく安定していることが確かめら れた。また、ラジウム濃度も殆んど変動がなかった。

地下水中のラドン濃度执よび $\mathrm{Ra} / \mathrm{Rn}$ 比に変動が認められなかったことから，この調査期間を通じ て，祖父江温泉の附近の地下の基盤に変動がなかったものと推定される。

この調査に当って地球化学上の御指導を頂いた名古屋大学理学部地球化学研究室杉崎隆一博土, 地 質学上の御指導を頂いた名城大学理工学部桑原徹教授, 液シン法によるラドンの測定法について御指 導を頂いた日本分析センタ一野口正安博土，東京大学理学部化学教室脇田宏博土，和よび本稿の御校 閲を頂いた愛知県衛生研究所長井上裕正博土に深謝致します。

本稿の要旨は1976年度日本地球化学会年会（昭和51年10月）に挴いて発表した。

\section{文献}

1）大野武男，小瀬洋喜（1971）：温泉の泉質に関する研究 川一超深層地下水の水質，温泉工会誌， Vol. 8, No. 1, $1 \sim 8$.

2）佐藤幸二（1973）：“非火山性”温泉に関する研究, 温泉科学, Vol. 24, No. 2, 55～64.

3）茶谷邦男, 中島治男, 林 閏一（1971）：濃尾平野の超深層地下水について（第 1 報）, 愛知 衛所報, No. 21，103〜 109 .

4）茶谷邦男, 中島治男, 浜村憲克（1974）：濃尾平野の超深層地下水について（第 2 報）主とし て水質の経時変動について, 愛知衛所報, No. $24,15 \sim 24$.

5）脇田宏, 野津憲治, 中村裕二, 浅田敏, 野口正安, 森岡正名（1974）：地下水中のラドン濃度 の変化による地震の予知, 1974年度地球化学討論会要旨集, 159.

6）脇田宏 (1974) ：ラドン放出量測定による地震の予知, Isotope news, No. 7, 10１1.

7）脇田宏（1976）：地球化学的方法による地震予知の研究，ぶんせき，No. 1，16２2.

8）桑原徹 : 私信

9）厚生省（1957）：衛生検査指針 VI 鉱泉分析法指針（改訂）

10）茶谷邦男，加賀美忠明，浜村憲克（1975）：環境中のトリチウムの測定（第 1 報）測定法の検 討, 愛知衛所報, No. $26,1 \sim 8$.

11）野口正安（1964）：液体シンチレーターによる Radon の放射能測定, Radio isotopes, Vol. 13, No. $5,362 \sim 367$.

12）脇田宏：私信

13）加賀美忠明，茶谷邦男，富田伴一，大沼章子，荘加泰司，森田登喜子，浜村憲克（1976）：液 体シンチレーションカウンターによる地下水中のラドンの測定について，第13回全国衛生化学技 術協議会要旨集, $110 \sim 111$.

14）富田伴一，茶谷邦男，加賀美忠明，大沼章子，荘加泰司，森田登喜子，浜村憲克（1976）：愛 知県尾張地区の地下水中のリン酸濃度について, 愛知衛所報, No. $27,9 \sim 11$.

15）浜村憲克，茶谷邦男，富田伴一，大沼章子，荘加泰司，加賀美忠明，森田登喜子，井上裕正 （1976）：愛知県尾張地区に拈ける地下水について，1976年度日本地球化学会年会要旨集，45. 
16）杉崎隆一, 吉本泰介, 加藤喜久雄, 杉浦孜（1963）：南関東ガス田の地球化学的考察一とくに ガス成分と鉱床の存在状態との関連について一, 地質誌, Vol. 69, No. 809, 67〜81.

17）木越邦彦（1973）： ${ }^{234} \mathrm{U} /{ }^{238} \mathrm{U}$ による地下水の年代測定, 1973年度地球化学討論会要旨集, 82.

18）脇田宏，野津憲治（1976）：地球化学的方法に上る地震予知論文集，1４.

（受付：1977年 8 月 4 日, 受理 : 1977年 9 月13日） 